\title{
Kerkwees in die saeculum vandag, Deel 2: 'n Nuwe narratief (ook vir die Nederduitsch Hervormde Kerk van Afrika)
}

\begin{abstract}
Author:
Tanya van $\mathrm{Wyk}^{1}$

Affiliation:

${ }^{1}$ Department of Dogmatics and Christian Ethics, University of Pretoria, South Africa

Note:

This article is the second of two which represent a reworked version of aspects from Chapter 1 of the PhD dissertation (University of Pretoria), entitled 'Die kerk as heterotopiese ruimte: ' $n$ Trinitariese model vir die derde millennium', with Prof. Dr Johan Buitendag as supervisor.
\end{abstract}

\section{Correspondence to:}

Tanya van Wyk

E-mail:

tanya.vanwyk@up.ac.za

Postal address:

Private Bag X20, Hatfield

0028, Pretoria, South Africa

Dates:

Received: 31 May 2012

Accepted: 06 July 2012

Published: 09 Oct. 2012

How to cite this article: Van Wyk, T., 2012, 'Kerkwees in die saeculum vandag, Deel 2: 'n Nuwe narratief (ook vir die Nederduitsch Hervormde Kerk van Afrika)', HTS Teologiese Studies/ Theological Studies 68(1), Art. \#1282, 8 pages. http://dx.doi.org/10.4102/ hts.v68i1.1282
C 2012. The Authors. Licensee: AOSIS OpenJournals. This work is licensed under the Creative Commons Attribution License.
Being church in the saeculum today, Part 2: A new narrative (also for the Netherdutch Reformed Church). A previous article illlustrated that the root of the tension between unity and plurality in the church can be found in an epistemology charcaterised by binary opposisions. This article describes this epistemology and, from the perspective of narrative theological epistemology, discusses the struggles and pitfalls reflected in the narrative of the Netherdutch Reformed Church of Africa which identifies itself as an 'ethnic church' (volkskerk). The article argues that such a self-identification functions as a metanarrative that is in conflict with the church's grand narrative, that of the Triune God. The re-telling of the grand narrative of the Trinity as the metaphor for unity through plurality will sustain the re-telling of the church's narrative in the changing context of a secular society.

\section{Inleiding}

\section{Die gevaar van onegte eenheid in kerkwees}

In die eerste van twee artikels is die epistemologiese voorwaardes bespreek wat kan bydra dat kerkwees in vandag se gesekulariseerde samelewing betekenisvol kan wees. Een van die belangrikste uitdagings is om die eenheid van die kerk te midde van pluraliteit te manifesteer. Met die opkoms van die ekumene na die Tweede Wêreldoorlog (Key et al. 1997:371-381) het 'n nuwe versoenende metanarratief begin vorm aanneem, naamlik om, ten spyte van die hegemoniese ideologie in die ekklesiologie, die eenheid van die kerk te midde van verskeidenheid te bevorder. Duitse en Nederlandse teoloë, sowel Rooms-Katoliek as Protestant, wat 'n sterk bydrae tot die ekumeniese beweging gelewer het, was onder andere Küng (1988), Schillebeeckx (1989) en Moltmann (2008). Hulle het bygedra tot 'n verruimende ekklesiologie in die Rooms-Katolieke Kerk en in die Protestantse wêreld. Hierdie veelkerklike fokus het so ver uitgekring dat goeie verhoudings opgebou is ook met teoloë in die Oosters-Ortodokse kerke waar 'n soortgelyke verruimende epistemologie en teologie nagestreef is.

Onder hulle neem die Kroatiese teoloog Volf, wat sterk deur die denke van Moltmann beïnvloed is, 'n belangrike plek in. Sy teologiese beredenering van die verband tussen ' $n$ relasionele ekklesiologie en 'n relasionele triniteitsbeskouing lewer ' $n$ waardevolle bydrae. Sy standpunt is ewewigtig: Aan die een kant maan hy dat 'one should not ... over-estimate the influence of trinitarian thinking on political and ecclesial reality' (Volf 1998:194; beklemtoning oorspronlik) en aan die ander kant redeneer hy dat 'the correspondence between the trinitarian and ecclesial relationships is not simply formal. Rather, it is "ontological" because it is soteriologically grounded' (Volf 1998:195; vgl McFadyen 1992:14). Volf (1998) het waardering daarvoor dat die communio in kerkwees likwiditeit veronderstel. Hy formuleer dit soos volg:

for a sojourning church [vloeibare/likwiede], only a dynamic understanding of its correspondence to the Trinity is meaningful. If the church remains at a statistically understood minimum of correspondence to the Trinity, it misses possibilities that God has given it along with its being; if by contrast it reaches it for a statistically understood maksimum, it risks missing its historical reality, and certainly if it claims to realize this maximum, its self-understanding turns into ideology. (bl. 200)

In Volf se denke oorstyg soteriologie formalisme en maak dit kerkisme onmoontlik. In ooreenstemming met Moltmann beklemtoon hy die pneumatiese dimensie in die versoening tussen mens en God. Dit bring Volf (1998:211) daartoe om die fokus op die 'life-giving ambience of the Spirit, not the person of the Spirit' te laat val. In die Triniteit is dit die Gees wat die interrelasie tussen die personae formaliseer: '[T] he unity of the triune God is grounded neither in the numerically identical substance nor in the accidental intentions of the persons, but rather in their mutually interior being' (Volf 1998:210; beklemtoning oorspronklik). Die 'mutually interior being' in hierdie aanhaling wys op die communio in sowel die Triniteit as in kerkwees. Dit wys ook daarop dat die Gees in die 
kerk as liggaam van Christus die ruimte vir die onderlinge eenheid van die lede en hulle deelhê aan God skep (Volf 1998):

Each person gives of himself or herself through others, and each person in a unique way takes up others into himself or herself. This is the process of mutual internalization of personal characteristics occuring in the church through the Holy Spirit indwelling Christians. The Spirit opens them to one another and allows them to become catholic persons in their uniqueness. It is here that they, in a creaturely way, correspond to the catholicity of the divine persons. (bl. 211-212)

'n Soortgelyke analogie tussen samelewing en Triniteit word by die Rooms-Katolieke teoloog Boff (2009) aangetref:

If one wants to achieve some understanding of the Holy Trinity one must take on this way of thinking and seeing the world. Suddenly, one discovers relations and realizes that everything is relation. The employed terminology itself already presupposes relations: there is no Father without a Son, no Son without a Father. There is no Breath (this is the meaning of Holy Spirit) without someone breathing. The Holy Spirit is the Breath of the Father into the Son and the Breath of the Son into the Father ... I emphasize that the three doesn't stand for the mathematical number within this context, it rather stands for the understanding that under the concept God there are differences that are not exclusive but inclusive, that are not opposing but in communion. The defining feature here is the union through relation, communion, and love. (bl. 120-121)

Wanneer Volf (1998:198-199) 'n analogie tussen die Triniteit en kerkwees sien, is hy terdeë bewus van die filosoof Immanuel Kant (1724-1804) se huiwering om enigiets vir die praktiese lewe uit die Triniteitsleer af te lei. Kant maak 'n onderskeid tussen die 'teoretiese rede' en die 'praktiese rede' en is besonder versigtig vir wat hy 'dogmatisme' genoem het (kyk na Friedrich [1977:70-115] se weergawe van Kant se Prolegomena zu einer jeden künftigen Metaphysikdie als Wissenschaft wird auftreten können wat in 1783 verskyn het). Ten spyte van Kant se huiwering om die 'teoretiese' begrip Triniteit te gebruik om vir die praktiese lewe analogieë af te lei, beskou Volf (1998:199) dit nie as 'n probleem nie.

Volf, beïnvloed deur die Kantiaanse dialektiek, sou egter tog nie 'n direkte verband tussen Triniteit en kerkwees wou postuleer nie. Daar kan hoogstens van analogieë gebruik gemaak word. Indien ' $n$ verband tussen Triniteit en kerkwees erken sou word, bly 'n mens bewus daarvan dat 'n postulaat geskep is. Vanuit die 'teoretiese rede' is ' $n$ waarde vir die 'praktiese rede' gepostuleer. Die dialektiek tussen wat Berger (1990) die simboliese wêreld en die sosiale wêreld noem, oftewel tussen die Goddelike en die menslike, kan alleen met behulp van metaforiese en/of analogiese taal uitgedruk word. Deur die indirekte verband tussen die Goddelike en die menslike in die oog te hou, begrond Volf sy ekklesiologie in die Triniteit deur van die begrip 'openbaring' (revelation) gebruik te maak. Hy meen dat hierdie begrip dit moontlik maak om die verband tussen Triniteit en kerkwees as 'n vanselfsprekende moontlikheid te reken. God se self-openbaring manifesteer op 'n hierdie-wêreldse wyse. Spiritualiteit stel mense in staat om daarvan bewus te word, dit raak te sien en betekenis vir hulle lewe daarin te vind. Hy formuleer die 'correspondence of ecclesial to trinitarian communion' soos volg (Volf 1998):
Here the correspondence acquires an inner dynamic, moving between the historical minimum and the eschatological maximum [Berger se 'simboliese universum']. For a sojourning church only a dynamic understanding of its correspondence to the Trinity is meaningful [Berger se 'sosiale universum']. If the church remains a statically understood minimum of correspondence to the Trinity ['n dogmatistiese direkte identifikasie tussen God en kerk] it misses possibillities God has given it along with its being; if by contrast it reaches for a statically understood maximum ['n dogmatiese indirekte identifikasie tussen God en die kerk sonder demistifisering] it risks missing its historical reality, and certainly if it claims to realize this maximum, its self-understanding turns into ideology. In none of these ... cases would the correspondence of the church to the Trinity do justice to the character of the church as a sojourning people of God. (bl. 200)

Die vraag is egter hoe hierdie analogie (correspondence) beskryf kan word en of dit enigsins relevant en van betekenis is. Die 'hoe' kan beantwoord word deur te probeer verstaan hoe die perichoresis in die Triniteit funksioneer. Die relevansie word duidelik wanneer die gevaar van vermeende eenheid, veral hoe dit in Protestantse ekklesiologie manifesteer, geïdentifiseer word. In die Reformatoriese kerke bestaan daar 'n verskeidenheid teologiese nuanses wat die eenheid van die kerk in gedrang bring. Lutherse oortuigings het gelei tot die gevaar dat ' $n$ 'mistieke eenheid' tussen die lidmate en Christus ook die onderlinge gemeenskap tot dié van 'n 'mistieke eenheid' beperk. 'n Calvinistiese nuanse loop die gevaar dat eenheid daaruit bestaan dat dieselfde notae bely word, naamlik dat die Woord suiwer verkondig en die sakramente suiwer bedien word, sonder dat dié belydenis tot ' $n$ konkrete gestalte van onderlinge gemeenskap lei. Sakramentalisme het egter ' $n$ verdelende faktor in kerkwees geword. Thiselton (2007) beskryf 'n hermeneutiek wat so "n verdeling' kan vermy, soos volg:

For this reason a valid hermeneutic of understanding would ask not in the abstract, 'How many sacraments are there?' but 'How does a sacrament function and what might be its nature or status within the following contexts': (a) within a seven-sacrament system; (b) within a two 'dominical' sacrament system; (c) within an 'incarnational' life-as-sacrament system; (d) in relation to theology of baptism; (e) in relation theology of Holy Communion; (f) in relation to questions about ordination and marriage; and so on. (bl. 511)

Die teologiese verskeidenheid in Calvinistiese en Lutherse kringe onderskeidelik het die eis om eenheid onder druk geplaas. Beide nuanses - eenheid in belydenis en mistieke eenheid - het daartoe gelei dat die eenheid van die kerk as 'n onsigbare entiteit verstaan word eerder as dat dit as 'n sigbare konkrete entiteit uitgeleef word. Beide hierdie variasies het ' $n$ negatiewe uitwerking op eksistensiële kerkwees. Dit het gelei tot ' $n$ groeiende onvermoë om verskeidenheid te hanteer. In plaas daarvan dat eenheid die eksistensiële imperatief is, het die handhawing van verskeidenheid die imperatief geword.

In die Nederduitsch Hervormde Kerk van Afrika (NHKA) het die beklemtoning van die eenheid van die kerk as 'n onsigbare entiteit (Engelbrecht 1978:11-14: Van Wyk \& Buitendag 2008:1447-1473) bepaalde gevolge gehad. Die kerk het eerder verskeidenheid gehandhaaf as wat dit probeer het om eenheid te bewerkstellig. Dit het sigbaar 
geword daarin dat dié wat fenotipies anders is, gemarginaliseer is. Nasionalisme en rassisme is twee ideologieë wat hieruit voortgespruit het. Die eis om eenheid te konkretiseer, is 'n radikale eis. In die kerk as geloofsgemeenskap moet die verskeidenheid - 'n realiteit - in Christus oorkom word. In Christus is daar nie meer Jood of Griek, man of vrou nie (Gal 3:28) hoewel daar altyd Jode, Grieke, mans en vrouens sal bestaan. Wanneer verskeidenheid beklemtoon en teologiese substansie daaraan gegee word - in werklikheid ideologiese mistifikasie - word die eis om eenheid gesystap. Teoreties word die belydenis van die eenheid gehandhaaf, maar in werklikheid word dit nie geleef nie.

Hierdie artikel het as doel om te argumenteer dat 'n epistemologie van binêre denke ten grondslag lê van kerkwees wat met die postmoderne kultuur uit pas is. Die artikel fokus op die Nederduitsch Hervormde Kerk (NHKA) as gevallestudie.

\section{'n Transendering van 'n epistemologie van binêre denke}

Hierdie ongeregverdigde oorbeklemtoning van verskeidenheid wat konfessioneel gesubstansieer is, is epistemologies in binêre denke, oftewel 'n digotomie gegrond. Die Westerse kultuur word gekenmerk deur digotomie. Snow (2001) meen dat die Westerse gemeenskap in 'n argument culture ontaard het. Dialoog word gekenmerk deur 'n opposisie-mentaliteit, waarin die sogenaamde wen-kant die waarheid 'het' soos 'n trofee (Tannen 1983):

The warlike atmosphere ... that makes us approach public dialogue ... urges us to approach the world - and the people in it - in an adversarial frame of mind. It rests on the assumption that opposition is the best way to get anything done ... that opposition leads to truth. (bl. 3)

Dit het 'n lang aanloop in die teologie. In die digitale bron Whitecrow Borderland, getitel, Binary opposition, hierarchy, and God's power in Early Christian writing ${ }^{1}$ word hierdie binêre denke in die teologie-geskiedenis soos volg beskryf:

In die geskiedenis van die vroeë kerk het 'n kompleks van verweefde idees na vore gekom wat die mees basiese aspekte van Westerse ideologie definieer. Hierdie idees het so lank dieselfde gebly dat hulle onaantasbare gesag begin kry het. Hulle is verhef tot die status van onveranderlike waarhede. Hierdie epistemologie is as gevolg van die lang geskiedenis daarvan nie sonder weerstand in die teologiese diskoers bevraagteken nie. Dit het miskien selfs onmoontlik geword vir iemand wat geskool is in Westerse denke om ' $n$ rasionele diskoers te bedink wat nie afhanklik is van konsepte wat gegrond is in binêre opposisies, hiërargiese strukture en die idee van 'n almagtige wese wat alles in aansyn geroep het en dit onderhou nie. Dit word onmoontlik om kritiek in te bring teen die geldigheid hiervan. (my parafrase)

Binêre denke gaan terug op Plato (Elbow 1993:51-78). In die geskiedenis van die teologie is Tertullianus van Karthago se denke ' $n$ voorbeeld hiervan. Hy is bekend vir sy kriteria om kettery (herēsis) uit te wys. Sedert die polemiese geskrifte van die kerkvaders het die spanning tussen ortodoksie (regte leer)

1.Kyk http://www.mayanastro.freeservers.com/01binaryopp.HTM, geraadpleeg op 19 Maart 2012. en heterodoksie (dwaalleer) teologiese argumentvoering begin bepaal. Die waarheid van proposisies kon onder andere deur die ouderdom van die uitsprake bepaal word. Hoe ouer, hoe nader aan die waarheid. Vir Tertullianus was 'apokrief' gelyk aan 'laat', na-kanoniek en ook heterodoks (vals) (Metzger 1987). Dit het die gevolg dat slegs proposisies in die kanonieke Bybel as waar erken is. Dit lei daartoe dat vermeende 'nuwe' idees maklik as dwaalleer afgemaak kan word. Dit beteken dat self-kritiek onmoontlik word en dat kritiek van buite moeilik aanvaar word. Wat 'anders' is, word hiperkrities afgewys sonder om te besef hoeveel vooroordeel onderliggend aan die oordeel is. Die gebrek aan insig in hoe oordele gefel word, spruit voort uit binêre denke. Binêre denke maak insig in binêre denke onmoontlik.

Die dominante diskoers straf die 'afwykende' denkers. Die vroeë kerkvaders het nuwe (heterodokse) teologiese denke in die kiem gesmoor deur die persoon wat daarmee vorendag gekom het, te skors of uit te ban. Later, toe die kerk die amptelike godsdiens van die Romeinse Ryk geword het, is sulke denkers met die dood op die brandstapel gestraf. Die denke van binêre opposisies en hiërargiese strukture, wat in die bestaan van 'n 'Almagtige Skepper' gegrond word, kan nie sonder meer as 'waar' beskou word net omdat die idees lank bestaan het en diegene wat met nuwe idees gekom het, skerp afgewys is nie. Die idee dat God, as suiwer Syn en krag (vgl. NGB 2), hoog bo die skepping verhewe is, lei noodwendig tot vervreemding tussen God en die skepping. Dit is die eerste tree na die ideologie van hiërargiese en binêre opposisies. Met so 'n ideologie word alle sosiale verhoudings deur mag bepaal. Solank as wat die kerk mag oor individue gehad het, is hierdie denke verskans - nie omdat dit noodwendig 'waar' is of die waarheid akkuraat omskryf nie, maar omdat dié wat daarteen ingegaan het, gestraf is. Mag word nie maklik prysgegee nie. Dit word die manier waarop mense met mekaar omgaan. God word gebruik om dit te legitimeer (Berger \& Luckmann 1975:85-148; Berger 1990:7, 33; vgl. Buitendag 2011:3). God se verhewenheid bo die mensheid word die regverdiging vir mense om hulleself as verhewe bo ander te beskou. Binêre denke het heteronormatiwiteit tot gevolg.

Heteronormatiwiteit is altyd ' $n$ hegemonie. Foucault (1982:778) beskryf die hegemonie van heteronormatiwiteit wat 'n dominante diskoers in Westerse denke geword het, soos volg: So 'n hegemonie beheer mense se lewens sonder dat hulle daarvan bewus is. Alles word in terme van binêre opposisies geïnterpreteer, of dit geslagtelikheid is, of dit nasionaliteit en etnisiteit is, en of dit religieusiteit is. Binne so 'n dinkraamwerk word uitdrukkings soos 'kerk vs. sekte' gebruik. Hierdie hegemonie het 'n kragtige negatiewe uitwerking op die ekklesiologie: Eenheid en verskeidenheid het uitsluitende begrippe geword. So 'n diskoers werk verlammend in op die etiek. Versoening en akkommodering word bykans onmoontlik gemaak. Aan die een kant is eenheid ' $n$ ideaal. Aan die ander kant is die handhawing van verskeidenheid 'n sine qua non. Binêre denke maak dit baie moeilik om 'eenheid' te midde van en ten spyte van verskeidenheid te verwerklik. 
Binêre denke onderskei tussen diegene wat binne is en diegene wat buite is. Dit blyk reeds uit die bekende spreuk van Thascius Caecilius Cyprianus van Karthago in die derde eeu (in sy Epistula 73.22): extra ecclesiam nulla salus est (buite die kerk geen saligheid) (in Neuner \& Roos 1954:213). Hiermee is die binêre kode inklusiwiteit-eksklusiwiteit wat met die binêre opposisie ortodoksie-heterodoksie gepaard gegaan het, versterk. Die geskiedenis van die kerklike konsilies is 'n getuienis van hoe daar in die verlede met hierdie binêre opposisies geworstel is. Die ekumeniese simbole en die formuliere van eenheid was die literêre produkte van hierdie geskiedenis. Die eenheidstrewe grondliggend hieraan het nie die binêre opposisies opgehef nie, maar 'n volgende binêre kode tot gevolg gehad, naamlik die sigbare-onsigbare aard van die kerk en die kerk se eenheid. Oorbeklemtoning van die sigbare aard van die kerk lei tot die ideaal van (gedwonge) organisatoriese kerkeenheid. Die oorbeklemtoning van die onsigbare aard van die kerk het gepaard gegaan met die regverdiging van aparte kerke wat op die verskeidenheid van menswees gegrond was (Loader 2009:4-5). Hoewel die getuienis hiervan duidelik in die geskiedenis van Afrikaanssprekende kerke gedurende die afgelope twee eeue sigbaar is, is die grondliggende binêre epistemologie na die hoogbloei daarvan in die Europese Aufklärung-denke terug te voer. In die teologie was die hart van hierdie denke die binêre kode rede-geloof.

Verskeie ander kodes het algaande in die kerk se geskiedenis ingetree: denominasioneel- ekumenies; fundamentalistiesrelatiwisties; geloof-ongeloof. Die kodes kon nie ideologiese ondertone ontkom nie: konserwatief-liberaal en fundamentalisties-relatiwisties. Sogenaamde 'ismes' het 'n rol begin speel in die manier waarop daar oor die eenheid en verskeidenheid van die kerk gereflekteer word:

- humanisme

- biblisisme

- independentisme

- separatisme

- nasionalisme

- rassisme

- universalisme

- partikularisme

- holisme en ook later seksisme

- homoseksualisme.

Dit het deel van die vanselfsprekende werklikheid van die kerk se bestaan geword. Dit is (en word) nie bevraagteken nie. Hoe groter die verskeidenheid op die verskillende vlakke van individu, denominasie en kerk, hoe groter word die probleem. 'n Volgende vlak van verskeidenheid dwing die kerk om aan te hou bestaan in die eenheid-verskeidenheid, maar ook vrae oor die aard van hierdie eksistensie te vra, te wete die verhouding tussen die Christelike godsdiens en ander gelowe (Küng 1988:186).

Cruz (2010:85-89) verwys na Knitter (2002) se bydrae ten opsigte van trajekte in die Christelike teologie se intergodsdienstige gesprek, naamlik eksklusiwisme en inklusiwisme. Eksklusiwiste sien ander godsdienste as vals.
Daarom moet hulle 'vervang' word. Knitter (2002:50-56) beskryf dit as 'n replacement model. Hierdie soort eksklusiwisme is ekklesiosentries. Volgens Cruz (2010:87) is die uitdrukking extra ecclesiam nulla salus tekenend daarvan dat gelowiges van ander godsdienste gemarginaliseer word. Cruz (2010) beskryf die ander trajek, inklusiwisme, soos volg:

Inclusivism is a liberal progression of this first position [eksklusiwisme]. Karl Rahner's theory of the 'anonymous Christian' best captures this stance. Peoples of other religions can attain salvation but it is Christ that is secretly saving them, even as they know nothing about it. These people are saved not so much in and through their own religions but despite their belonging to them. Pluralism, meanwhile, basically asserts that no religion, including Christianity, can claim to be the norm or guide by which others are measured. (bl. 87)

Ekklesiosentrisme is met ander woorde gegrond in die vooroordeel dat ander godsdienste gedeeltelik waar is. (Eksklusiewe) ekklesiosentrisme wat Christosentrisme (Cruz 2010:88) geword het, wil ander godsdienste dan vervul, voltooi of vervolmaak. Knitter (2002:76-80) beskryf dit as die fulfillment model. Die binêre denke onderliggend hieraan word nie raakgesien nie. Dit maak van sowel ekklesiosentrisme as Christosentrisme ' $n$ 'isme'. Dit beteken egter nie dat die eksistensiële waarde van Christenwees hiermee gerelativeer is nie. Die uitdaging is om Christen in die ekklesia te wees en om op 'n uitnodigende wyse oop te wees vir ander en nie op 'n hegemoniese wyse met ander om te gaan nie. So 'n meer eksistensiële dinamiese Christen-wees word aangetref by Dietrich Bonhoeffer wat in die gevangenis ' $n$ openheid gehad het vir die ander wat hom sy bestaansreg ontneem (Bonhoeffer 1951).

Die 'isme'-denke as gevolg van die binêre mentaliteit het 'n sterk invloed op kerkwees in Suid-Afrika gehad. Bogenoemde twee trajekte kan raakgesien word in die debat wat in die kerk in Suid-Afrika veral op die spanning eenheid-verskeidenheid fokus. Eksklusiwisme het kerkisme tot gevolg. Een denominasie wat nie kan bestaan sonder om in verhouding met ander dominasies te staan nie, leef asof die eie die enigste is en die ander moet konformeer. Dit is 'n verskynsel wat in die natuur aangetref word. Paulus noem dit 'n kata sarka bestaan. George Orwell (1945) beskryf hierdie menslike gedrag in sy parodie Animal Farm as: 'all animals are equal, but some are more equal than others.' In die NHKA weerspieël kerkisme nie net die verhouding tot ander denominasies nie. Die kerk se vashou aan die volkskerkideologie is 'n uiterste vorm van so 'n kerkisme. Etniesgegronde volkskerke is waar mense se kata sarka kenmerke die grond vir eksklusiwisme word. Die 'isme' in terme van etnisiteit geld ook 'isme' in terme van geslagtelikheid. Die anders-denkende, andersbelydende, anderskleurige, andersseksuele kan nie ingesluit word nie. Die werklikheid van verskeidenheid word oorbeklemtoon.

Die remedie vir eksklusiwisme is nie inklusiwisme ('n volgende 'isme') nie. Indien inklusiwisme gemaklik met eksklusiwisme vervang word, het ons te doen met die verskynsel wat Cruz (2010:87-88; vgl. White 1973:2) 'liberal 
progression' en Storrar (2008:15; vgl. Simpson 2002:139) die 'repressive tolerance' noem. Liberalisme is ' $n$ ewe groot epistemologiese struikelblok as konserwatisme. Albei is nie oop vir akkommodering en toleransie nie. Nie een van die twee dra daartoe by om die spanning eenheid-verskeidenheid in kerkwees op 'n positiewe wyse te verwesenlik nie. Albei kan die eenheid van die kerk in gedrang bring: 'n Oorbeklemtoning van verskeidenheid is nie die oplossing vir die probleem van die oorbeklemtoning van die eie nie. 'n Ongenuanseerde beklemtoning van eenheid sonder die akkommodering van verskeidenheid is insgelyks 'n produk van binêre denke. Dit berus op die 'geloof' dat 'ek' die waarheid 'het' en dit aan ander moet verduidelik/afgee/ oortuig, sodat hulle kan 'inkom'. Die anders-denkende, andersbelydende, anderskleurige, anders-seksuele kan 'inkom'. Met die 'inkom' word die ander vervolmaak: Die eie tradisie en heterodenke vervolmaak die onvolledige. Die imperatief van eenheid word oorbeklemtoon.

Ook in die NHKA het die term 'gesonde spanning' kenmerkend van 'n verdoeseling van binêre denke geword. Dit kan met verwysing na dieNHKA se geskiedenis aangetoon word. Die debat oor diversiteit (op hierdie stadium met betrekking tot etnisiteit en seksualiteit) het in 'n binêrekodedebat ontaard, met die 'ismes' as voertaal. Die hoofwoorde van hierdie voertaal is inklusiwisme en eksklusiwisme. Ander woorde van die voertaal is homoseksualisme, heteroseksualisme, rassisme, humanisme en liberalisme. Die probleem is dat die toenemende verskeidenheid tot 'n toenemende onbehendigheid met verskeidenheid lei. Die gevolg is dat die eenheid van die kerk al hoe meer in die gedrang kom.

Daar kan uit hierdie impasse beweeg word as kerkwees verstaan kan word in terme van 'n ellips met eenheidinklusiwiteit en verskeidenheid-eksklusiwiteit as die twee fokuspunte. Die aanwesigheid van sowel inklusiwisme as eksklusiwisme in die NHKA (en die Nederduitse Gereformeerde kerk, NGK) voldoen nie aan die voorwaardes van so 'n ellips nie. Dit is veral sigbaar in die sakrament van die nagmaal - dié sakramentele handeling van die kerk waar die verskeidenheid in eenheid oorstyg moet word. Bajis (1989:147) beskryf in aansluiting by die werk van Holtzman (1973) die belang van die nagmaal vir die eenheid van die kerk soos volg:

The Church exists universally only because it exists Locally. The 'universal' Church can only be manifest in the Local Church, because the Eucharist can only be celebrated Locally. And it is the Eucharistic assembly, as the Body of Christ, which makes the Local Church transcend its geographical limitations. The foundation for this is seen in Paul's very description of the Church as 'the body of Christ' (1 Cor. 12:27). In fact, it is reasonable to assume that the very phrase 'body of Christ' had its origin in the Eucharistic assembly: 'In the Eucharist the body of Christians ( $t \bar{o}$ sōma tōn Kristianōn) becomes the body of Christ.' (bl. 85)

In die simboliese handeling van die nagmaal word die eenheid van die kerk as ellips gedemonstreer. In die nagmaal word verskeidenheid oorkom op grond van die koinonia wat die eenheid verwerklik. Collins (2008) vra wat dit vandag vir die kerk beteken om van eenheid en verskeidenheid te getuig:

The place of the heretic, the schismatic, the excommunicate and the (non-) religious Other in relation to the Eucharist and the Church raises profound questions about exclusion and inclusion and the status of those 'outside' and about space for the Other. How can the Church respond to demands for tolerance and hospitality? (bl. 139)

Sander (2010:171) beskryf die uitdaging vir die kerk vandag te midde van globalisering en sekularisering as om 'likwied' (liquid) te wees. As die kerk nie likwied (vloeibaar) is nie, nie oop is vir verskeidenheid nie, is die kerk nie meer likied (solvent) nie. ' $\mathrm{n}$ Kerk wat net vir sigself bestaan, sal bankrot raak. Likwiditeit impliseer dat daar nog vloeistof toegevoeg kan word en dat die houer dit moet kan bevat en moet kan rek. Die vloeibaarheid van die kerk is vir sommige bedreigend. Hierdie vrees word oorkom deur dit in 'n apokaliptiese utopie te projekteer. Eenheid is 'n eis. Verskeidenheid moet oorstyg word. Dit is egter so bedreigend om saam met ander te leef, dat die eenheid van die kerk 'n onsigbare toekomsideaal word. Apokalips veronderstel straf en beloning. Aan die einde van die tyd sal diegene wat die vrees veroorsaak het, gestraf word en die vresende sal gevindikeer word. Volgens Sander (2010:170) kan hierdie utopie gesien word in apokaliptiek waar verskeidenheid eskatologies opgelos word. Dit word met mag geassosieer. Dit behou die status $q u o$. Dit behels dat daar van die begin van die verhaal (Jesus) na die einde toe beweeg word. As die verstaan van die Jesussaak so uiteenlopend is dat die gevolg relatiwisme is, kan die uitkoms alleen in toekomsprojeksie gevind word. Die hoop is dat so 'n eskatologiese ekklesiologie die 'precarious liquidity' sal kan weerstaan. Hiervolgens is God verantwoordelik daarvoor om die magteloosheid van die verlede en hede finaal te verslaan en stabiliteit teweeg te bring. God is verantwoordelik daarvoor om die oplossing te verskaf omdat God saam met mense na geregtigheid en vrede smag. In so 'n apokaliptiese utopie is daar geen vloeibaarheid nie. Dit is nie getrou aan God nie (Sander 2010:177-178). Dit is deel van 'n moderne (binêr-georiënteerde) identiteit wat likwiditeit systap om magteloosheid te oorkom. Apokaliptiese aansprake is gelyk aan 'n soort 'godsdienstige tegnologie' wat daarop gerig is om jou eie utopie te verseker. Dit is gegrond op die self. Die toekoms sal die oorwinning bied. Die sekerheid van hierdie oorwinning is gegrond op 'n oortuiging dat die ander (verskeidenheid) uitgesluit/uitgewis moet word. Sanders (2010) stel dit soos volg:

Utopias give security for the future and accumulate power in the present ... for this purpose it is important for those who are longing for a final judgement about history that God's intentions on history are already known for them. (bl. 176)

Daar is egter ook 'n ander moontlikheid as 'n apokaliptiese utopie. Sander (2010:175-177) noem dit heterotopie. Hierdie begrip word aan Foucault (1984, 2001:1571-1581) ontleen. Heterotopie veronderstel dat die skynbaar onmoontlike (utopiese) moontlik word. Die eenheid realiseer nie in die toekoms nie, maar in die onmiddellike hede. Die vindikasie is daarin geleë dat die een oop is vir die Ander. In ekklesiologiese terme is heterotopie die verwerkliking van kerk-wees as 'n ellips - eenheid te midde van en selfs ten spyte van die Ander. 


\section{Die doel -'n nuwe narratief vir die Nederduitsch Hervormde Kerk van Afrika}

Die verhaal van die Nederduitsch Hervormde Kerk (NHKA of Hervormde kerk) is die verhaal van 'n kerk wat na inklusiwiteit op reis is (Buitendag \& Van Wyk 2011a en 2011b), maar nog nie as 'n 'wye oop ruimte' (Moltmann 2008) gekarakteriseer kan word nie. Dit is te danke aan die Hervormde Kerk se ekklesiologiese karakter. Die Hervormde Kerk bely saam met die kerk van alle eeue dat die kerk een, heilig, katoliek en apostolies is - 'n versoenende verskeidenheid. Die Kerk besef en bely dat die kerk inderdaad uit sondige en natuurbepaalde mense bestaan - man, vrou, wit, swart - maar slaag nie daarin om hierdie verskeidenheid te transendeer nie. Dit blyk enersyds uit die Hervormde Kerk se amptelike standpunte rondom homoseksualiteit - die méns, maar nie die daad is welkom in die 'wye oop ruimte' nie. Andersyds blyk dit ook uit die teologie van daardie teoloë wat aandring daarop dat die NHKA 'n 'volkskerk' moet wees - die anomalie dat alle mense deel van die kerk van Christus is, maar aan die 'eie kerk' (NHKA) mag slegs Afrikaanssprekende wit mense behoort. Die oorsaak daarvan is 'n gefragmenteerde teologiese antropologie, wat verband hou met die beginsel van 'geen gelykstelling' wat deur die Hervormde Kerk se teologiese antropologie nagevolg is. Dit kom daarop neer dat die Kerk die sigbare verskeidenheid as gegewe (indikatief) aanvaar en dit in 'n imperatief verander en dan die 'onsigbare' kerk wat eskatologies 'een' sal wees, bely (Buitendag \& Van Wyk 2011a, 2011b).

Dit sal van die NHKA vra om positief erns te maak met die 'postsekulêre apologetiek' van iemand soos McGrath (2012). McGrath (2012:140) sluit aan by Wright (1992:132) se 'alternative ways of thinking'. Dit is ' $\mathrm{n}$ narratief wat op 4 fundamentele vrae antwoorde bied:

- 'Who are we?' Ons is mense wat gemaak is na die beeld van die Skepper en 'are not given our fundamental identity by race, gender, social class, or geographical location'.

- 'Where are we?' Ons lewe in 'n wêreld wat mooi is, 'though transient'.

- 'What is wrong?' Ons weet dat ons teen ons Skepper rebelleer en 'the world is consequently out of tune with its created intention'.

- 'What is the solution?'

Anders as in die vroeë kerkgeskiedenis toe filioque nie tot kohesie in kerkwees gelei het nie, bly dit 'n uitdaging dat die 'hermeneutics of the doctrine of God as the Trinity (Thiselton 2007:451-478) in die huidige tydsgees tot 'n 'unity through diversity' (Cullmann 1986:13) kan bydra. Vir die NHKA veronderstel dit dat die kerk sal wees wat die Drieenigheid impliseer: eenheid te midde van pluriformiteit (verskeidenheid). So 'n likwiditeit vra dat die NHKA 'n nuwe bladsy in die narratief van die kerk oopmaak. Dit kan gedoen word deur die narratief van die kerk in terme van 'n relasionele Triniteit te beskryf. Dit is die 'storie van die kerk' wat in die ekonomiese/ekumeniese/relasionele Triniteit kondenseer. Met 'n verwysing na Jüngel (1976:11-15), beskryf Fiddes (2000) die belang van die leer oor die Triniteit soos volg:

For the church doctrine of God as Trinity attempts to model the conviction that God's life is relational, that the depth of God's personal being can only be expressed in terms of a dynamic interweaving of personal relationships ... The concept of the Trinity is not about observing God, not about participating in God. The self-opening of God in revelation entices us into engagement with God ... This interweaving or perichoresis of relationships can be expressed in a narrative way: God has a story within God's own self - the story of a Father, who sends out a Son in a Spirit of love and openness to the future. The story of the eternal birth of the Son from the womb of the Father continues in the historic story of the sending out of Jesus Christ ... This is the 'metanarrative' into which we are invited to encorporate our own stories. We are invited to let the reconfiguration of time in this Grand Story, its particular integration of past, present and future, shape the way we see past history and expect what is to come. Postmodern criticism has been suspicious of all meta-narratives, that is stories which claim to explain the whole of reality (though Derrida himself never thought they could be entirely erased), since they easily become ideologies which oppress persons in the name of absolute truth. But we have seen there is an openness in the way that a reader participates in this narrative which has hiddenness at its heart. (bl. 43-44)

Volgens hierdie insigte van Jüngel en Fiddes is kerkwees eksistensieel 'n verhaal op sigself. Dit is egter nie 'n selfstandige verhaal sonder ' $n$ inbedding in 'n groter verhaal nie. Die meesternarratief is dié van God se ontmoeting met mense en ander dinge in die skepping, en in hierdie narratief is elkeen van die persona van die Triniteit ' $n$ komponent van die verhaal van outentieke lewe - 'n lewe coram Deo; 'n lewe as manifestasie van God-met-ons. Hoe 'n mens Bybelsteologies of vanuit watter ander perspektief ook al redeneer, die begrip 'liefde' hoort as die sentrum van God-met-ons (Van Aarde \& Pelser 2001:36-37). Dit is waarop 'triadologiese

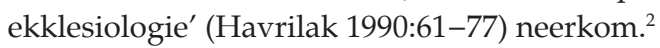

So 'n hermeneutiek van triadologiese ekklesiologie veronderstel dat daar nie (1) voorrang aan ' $n$ 'ekonomiese Triniteitsleer' ('God ad extra') bo 'n 'immanenente Triniteitsleer' ('God ad intra'), of omgekeerd, gegee word nie, maar ook nie (2) 'n eensydige interpretasie van die sogenaamde 'social doctrine of the Trinity' plaasvind nie (kyk na o.a. Kilby 2000:432-445; Metzler 2003:270-288; Hebbletwaite 2005:82-90; Chapman 2005:43-58), asof Van Ruler se begrip gratia praeveniens met 'n 'social gospel' vervang is.

Binne die konteks van 'n vroeëre debat in Nederland oor die kerk as 'volkskerk' oordeel Van Ruler (1947:506) dat

2.Soos vroeër in die studie aangedui, word met die begrip 'triadologie' beide die 'ekonomiese' as die 'immanente', oftewel die ontologies-sosiale én die ontologiesessensiele, aspekte van God as Drie-eenheid aangedui, Hierdie verryking van die Triniteitsleer is die gevolg van die invloed van teologiese insigte vanuit die 'Oosters-Ortodokse' kerk op die 'Westers-Ortodokse' kerk. In hierdie verband haa Peter Robinson (2007:59-60, endnota17) die Oosters-Ortodokse teoloog Gregory Havrilak (1990:61-77) soos volg aan: 'The basis of Eastern triadology is found in soteriology, in that its fundamental goal is to maintain the Christological and pneumatological presuppositions that (a) the incarnate logos and Divine Spirit are met and expressed first as divine agents of salvation, and (b) only then are they discovered to be essentially one God'). 
sy medelandgenoot Kohlbrugge se volkskerkteologie nie werklik erns maak met 'de politiek-culturele aspecten' van kerkwees wat van 'pneumatische realiteit der liefde' getuig nie. Van Ruler (1947) gaan dan onmiddellik daartoe oor om nie ruimte te laat dat humanisme hoegenaamd vanuit sy eie teologie afgelei kan word nie:

Accentueeren wij daartegenover het moment van de liefde, dan dient echter wel met bijzonderen nadruk vastgehouden te worden, dat de liefde enkel en alleen in de verbrijzeling geboren wordt. Waarachtige liefde ontstaat eerst in de erkenning, dat wij tot de liefde niet in stáát zijn. En deze erkenning is niet alleen haar oorsprong, maar ook haar vorm. De liefde wordt niet allen uit deze erkenning gebóren, maar zij bestáát ook in deze erkenning. Dáárin pas gaat het niet meer om ònze gerechtiheid, maar om de gerechtigheid Gods; niet om het goed doen, maar om het goed zijn; niet om het gerechtigheid doen, maar om de gerechtigheid zélve. Deze erkenning van onze onmacht, deze radikale verbrijzeling is de schuldbelijdenis. (bl. 506-507)

In sy boek Ter wille van hierdie wêreld: Politiek en Christelike heilsbelewing, opgedra aan Van Ruler op grond van die invloed van Van Ruler, het die teoloog van die Universiteit van die Witwatersrand, alumnus van die Universiteit van Pretoria en doktorale student van Van Ruler, Ben Engelbrecht (1982) die volgende oor die liefdeseis en die eenheid van die kerk gesê (gender-taalgebruik oorspronklik):

Die Christen aanvaar die wêreld nie as sy onvermydelike lot, dus met gelatenheid en berusting nie, maar gelowig, hoopvol, met liefde. Die aardse lewe is vir die gelowige één heilsbelewing, al word dit deur nog soveel teenstrydighede gekenmerk ... Die politieke verantwoordelikheid wat daar op die kerk rus, en wat in Suid-Afrika in toenemende mate deur hom besef behoort te word, stel hom op die pynlikste wyse voor die vraagstuk van sy verdeeldheid. Dit laat hom met die grootste erns staan voor sy ekumeniese aard en roeping om die kerk in die enkelvoud te wees. Om sy eenheid te soek en weer te vind, word vir die kerk deur sy politieke verantwoordelikheid beklemtoon as 'n onontwykbare Goddelike noodsaak. (bl. 88-89, 106)

Christen-wees in hierdie wêreld is om volgeling van die Seun te wees, om deur die Gees gelei te word en om deur die Vader versorg te word. Dit is almal verhale binne 'n verhaal. Dit is wat bedoel word as die verhaal van die lewe, oftewel die storie van die kerk, as 'n 'metanarratief' beskryf word. Wat Jüngel en Fiddes egter ook uitwys, naamlik dat hierdie perichoresis op relasies betrekking het, is dus belangrik. Ook hulle opmerking dat juis die distorsie in relasies, wat verwringing van menswaardigheid kan meebring en wat ook tot die oneer van God lei, is net so belangrik. Daarom is dit nodig om 'n hermeneutiek van suspisie toe te pas op die metanarratief wat die verhaal van die kerk is. Dit, sodat 'n nuwe narratief oor die kerk vertel kan word - ook vir die NHKA.

\section{Erkenning \\ Mededingende belange}

Die outeur verklaar dat sy geen finansiële of persoonlike verbintenis het met enige party wat haar nadelig kon beïnvloed in die skryf van hierdie artikel.

\section{Literatuurverwysings}

Boff, L., 2009, Saint Joseph: The father of Jesus in a fatherless society, transl. A Guilherme, Wipf Stock Publishers (Cascade Books), Eugene, OR.

Bajis, J., 1989, 'The meaning and importance of catholicity and the Local Church', in J. Bajis (ed.), Common ground: An introduction to Eastern Christianity, pp. 15-31, Light and Life Publishing, Minneapolis, MN.

Berger, P. \& Luckmann, P., 1975, The social construction of reality: A treatise in the sociology of knowledge, Penguin, Harmondsworth.

Berger, P., 1990, The sacred canopy: Elements of a social theory of religion, Anchor Press, New York, NY.

Boff, L., 2009, Saint Joseph: The father of Jesus in a fatherless society, transl. Guilherme, Wipf Stock Publishers (Cascade Books), Eugene.

Bonhoeffer, D., 1951, Widerstand und Ergebung: Briefe und Aufzeichnungen aus der Haft, Hrsg. von E. Bethge, Chr. Kaiser, München.

Buitendag, J., 2011, “"Epistemology models ontology”- In gesprek met John Polkinghorne', HTS Teologiese Studies/Theological Studies 67(1), Art. \#897, 9 pages. http://dx.doi.org/10.4102/hts.v67i1.897

Buitendag, J. \& Van Wyk, T., 2011a, 'Die NHKA oppad na inklusiwiteit, deel I: Die anatomie van 'n gefragmenteerde/eskatologiese ekklesiologie', HTS Teologiese Studies/ Theological Studies 67(3), Article \#1164, 8 pages. http://dx. doi. org/10.4102/hts.v67i3.1164.

Buitendag, J. \& Van Wyk, T., 2011b, 'Die NHKA oppad na inklusiwiteit, deel II: 'n Holistiese teo-antropologie as voorwaarde vir ekklesiologie', HTS Teologiese Studies/Theological Studies 67(3), Article \#1173, 10 pages. http://dx. doi.org/10. 4102/hts.v67i3.1173.

Chapman, M., 2005, 'Theologies of community and theologies of conflict', in M. Chapman (ed.), Blair's Britain: A Christian critique, pp. 43-58, Darton Longman and Todd, London.

Collins, P.M., The Trinity for the Perplexed, T \& T Clark, Edinburgh.

Cruz, G.T., 2010, 'God before us, God among us: Interreligious dialogue form an intercultural feminist perspective', in L. Boeve, F. Depoortere \& S. Van Erp (eds.), pp. 85-98 Edward Schillebeeckx and contemporary theology, T\&T Clark, London.

Cullmann, O., 1986, Unity through diversity, Fortress Press, Philadelphia.

Elbow, P., 1993, The uses of binary thinking, Journal of Advanced Composition 13(1), $51-78$.

Engelbrecht, B., 1982, Ter wille van hierdie wêreld: Politiek en Christelike heilsbelewing in Suid-Afrika, Tafelberg-Uitgewers, Kaapstad.

Engelbrecht, B.J., 1978, 'Die onderskeiding tussen "onsigbare" en "sigbare" kerk en die betekenis daarvan ten opsigte van die eenheid van die kerk', Almanak 72, 8-15.

Fiddes, P.S., 2000, 'Story and possibility: Reflections on the last scenes of the Fourth Gospel and Shakespeare's The tempest', in G. Souter \& J. Barton (eds.), Revelation and story: Narrative theology and the centrality of story, pp. 29-52, Ashgate, Aldershot.

Foucault, M., 1982, 'The subject and power', Critical Enquiry 8, 777-795, viewed 12 March 2012, from http://dx.doi.org/10.1086/448181

Foucault, M., 1984, 'Of other spaces: heterotopias' [Die artikel, getitel 'Des Espace Autres', is in Oktober 1984 in die Franse tydskrifl Architecture/ Mouvement/ Continuité gepubliseer en het gedien as basis van 'n lesing wat in Maart 1967 deur Foucault gelewer is.], transl. J. Miskowiec, viewed 14 June 2012, from foucault. info/documents/heteroTopia/foucault.heteroTopia.en.html.

Friedrich, C. J., 1977, The philosophy of Kant, edited with an introduction by C.J. Friedrich, M.L. Publishing, New York, NY. (The Modern Library).

Havrilak, G., 1990, 'Karl Rahner and the Greek Trinity', Saint Vladimir's Theological Quaterly 34, 61-77.

Hebblewaite, B., 2005, Philosophical theology and Christian doctrine, Blackwell Publishing, Oxford, viewed 12 March 2012, from http://dx.doi.org/10.1002 /9780470775714

Holtzman, J.J., 1973, 'Eucharistic ecclesiology of the orthodox theologians', Diakonia 8, 5-21.

Jüngel, E., 1976, The doctrine of the Trinity: God's being is in becoming, transl. H. Harris, Scottish Academic Press, Edinburgh.

Key, H.C., Frost, J.W., Albu, E., \& Lindberg, C., 1997, Christianity: Social and cultural history, 2nd edn., Prentice Hall, Upper Saddle River, NJ.

Kilby, K., 2000, 'Perichoresis and projection: Problems with social doctrines of the Trinity', New Blackfriars, October, 432-445, viewed 12 March 2012, from http:// dx.doi.org/10.1111/j.1741-2005.2000.tb06456.x

Knitter, P., 2002, Introducing Theologies of Religions, Orbis, Maryknoll, New York, NY.

Küng, H., 1988, 'Theology on the way to a new paradigm: Reflections on my own career' in H. Kung (ed.), Theology for the Third Millennium: An ecumenical view, pp. 182-206, transl. P. Heinegg, Doubleday, an Anchor Book, New York, NY.

Loader, J.A., 2009, 'Calvin's election mix in small-scale theology', HTS Teologiese Studies/Theological Studies 65(1), Art. \#337, 9 pages. http://dx.doi.org/10. 4102/ hts.v65i1.337

McGrath, A.E., 2012, Mere apologetics: How to help seekers and sceptics findfaith, Baker Books, Grand Rapids, Ml. 
McFadyen, A., 1992, 'The Trinity and human individuality: The conditions for relevance', Theology 95, 10-18.

Metzger, B.M., 1987, The canon of the New Testament: It's origins, development, and significance, Claredon Press, Oxford.

Metzler, N., 2003, 'The Trinity in contemporary theology: Questioning the social doctrine of the Trinity', Concordia Theological Quaterly 67, 270-288.

Moltmann, J., 2008, A broad place: An autobiography, Fortress Press, Minneapolis, $\mathrm{MN}$

Neuner, J. \& Roos, H., 1954, Der Glaube der Kirche in den Urkunden der Lehrverkündigung, Vierte verbesserte Auflage, hrsg. von K. Rahner, Verlag Friedrich Pustet, Regensburg.

Orwell, G., 1945, 'Animal Farm', viewed 14 June 2012, from http://www.amazon.com/ Animal-Farm-1984-George-Orwell/dp/0151010269/ref=sr_1_4?s=books\&ie=UTF 8\&qid=1339697391\&sr=1-4\&keywords=Orwell\%2C+George

Sander, H.J., 2010, 'Pushed to a precarious flexibility: Where to go if tradition has no answer and apocalypse is no alternative', in L. Boeve, F. Depoortere \& S. Van Erp (eds.), Edward Schillebeeckx and contemporary theology, pp. 163-182, T\&T Clark, London.

Schillebeeckx, E., 1989, The religious and human ecumene: The future of liberation Theology. Essays in honor of Gustaco Gutiérrez, Maryknoll, New York, NY.

Simpson, G.M., 2002, Critical social theory: Prophetic reason, civil society and Christian imagination, Fortress, Minneapolis, MN.

Snow, C.P., 2001, The two cultures, Cambridge University Press, London.
Storrar, W., 2008, 'The Pretoria Public Theology/Stellenbosch Dawid de Villiers public lectures 2008. A symposium on "Responsible South African public theology in a global area: Perspectives and proposals", organised by the Centre for Public Theology of the Faculty of Theology at the University of Pretoria, Pretoria, 04-05
August 2008.

Tannen, D., 1998, The argument culture: Stopping America's war of words, Ballantine Books, New York, NY.

Thiselton, A.V., 2007, 'The hermeneutics of the doctrine of God as Trinity', in A.V. Thsielton (ed.), The hermeneutics of doctrine, pp. 451-478, William Eerdmans Publishing, MI.

Van Aarde, A.G. \& Pelser, G.M.M., 2001, "n Oop en vry teologiese debat met werklike diepgang', HTS Teologiese Studies/Theological Studies 57(172), 7-48.

Van Ruler, A.A., 1947, De vervulling van de wet: Een dogmatische studie over de verhouding van openbaring en existentie, G.F. Callenbach N.V., Nijkerk.

Van Wyk, T. \& Buitendag, J., 2008, 'Die dimensies "eenheid" en "katolisiteit" in die ekklesiologie van die Nederduitsch Hervormde Kerk sedert Ottawa 1982', HTS Teologiese Studies/Theological Studies 64(3), 1447-1473.

Volf, M., 1998, After our likeness: The Church as the Image of the Trinity, Eerdmans Publishing Company, Grand Rapids, MI.

White, H., 1973, Metahistory: The historical imagination in nineteenth-century Europe, John Hopkins University Press, Baltimore, VA.

Whitecrow borderland, 2001, 'Binary opposition, hierarchy and God's power in early Christian writing', viewed 19 March 2012, from http://www.mayanastro. freeservers.com/01binaryopp.htm

Wright, N.T., 1992, Climax of the covenant: Christ and the law in Pauline theology, Fortress Press, Minneapolis, MN. 